\title{
Effect of Gender and Geographical Areas on Self Concept and Altruism of Secondary School Students
}

\author{
Arun Kumar*
}

\begin{abstract}
This study was conducted to see the effect of gender and geographical areas on self concept and altruism of secondary school students. The sample for the study was 100 students including 50 male and 50 female students. Out of 100 students, 50 students belong to rural and 50 students from urban areas. In this study two tools have been used (i) Self- Concept Questionnaire prepared by Dr. R.K. Saraswat (2011) (ii) Altruism Scale prepared by Dr. S.N. Rai and Dr. Sanwat Singh (2004) namely. The Self- Concept has no effect of gender difference and geographical areas. But altruism has significant effect of gender on secondary school students. Female students showed higher level of altruism than male students and geographical area also has considerable influence on the level of altruism of secondary school students. The self-concept and altruism of secondary school students have positively low correlation with each other.
\end{abstract}

KEY WORDS: Gender, Geographical Area, Self concept, Altruism, Secondary school students *Department of Education, University of Lucknow, Lucknow-226007, (U.P.), INDIA

\section{INTERODUCTION}

In nature, all human being are different, whether they are male or female. The difference may be due to the genetics and environmental effects and their interactions. In general, the psychophysical differences are biological and psychological. The biological differences are the result of genetics and they are mostly permanent in nature, while the psychological traits i.e. interest, motivation, need, self concept, and altruism etc. Generally get changed as the gender and environment change.

Marcengo and Rapp (2014) stated that the self concept has become the central theme of psychology to explain the human activities and their personality. There were number of psychologist namely Sigmund Freud, Alfred Adler, Carl Rogers and Abraham H. Maslow, who have contributed a lot in the field of self concept and development of its theory to explain personality. Carl Jung said that the self is a totality consisting of conscious and unconscious contents that dwarfs the ego in scope and intensity. The maturation of the self is the individualization process which is the goal of healthy personality. So one's self-concept is a collection of his views, ideas, attitudes about himself, what he does, how he behaves and appraisal of himself. Rogers (1951) said that a person's self-concept determines his behaviour and his relation to the world and that true therapeutic improvement occurs only when the individual changes his own self-concept.

Guimond, et.el. (2006) explained in their study that the self-categorization theory developed by John Turner states that the self-concept consists of at least two "levels": a personal identity and a social one. In other words, one's self-evaluation relies on self-perceptions and how others perceive them. Self-concept can alternate rapidly between the personal and social identity. According to Baumeister (1999), Self-Concept is the individual's belief about himself/ herself, including the person's attributes and who and what the self is. Henry Epps (2012) Altruism ( also called the ethic of altruism, moral altruism and ethical altruism) is an ethical doctrine that hold that individuals have a moral obligation to help, serve, or benefit others, if necessary, at the sacrifice of interest. August Comte's version of altruism calls for living for the sake of others. One who holds to either of these ethics is known as an 'altruist'. The concept of Altruism has a long history in philosophical thought. August Comte, the French founder of positivism, first introduced this term. According to him, Altruism was an unselfish regard for the welfare of others. The term 'Egoism' is just opposite of Altruism which means selfish, ego-centred and unsocial behaviour. He has also described the ethical doctrine and believed that individuals had a moral obligation to renounce self interest and live for others.

According to Wispe (1978), Altruistic behaviour is the behaviour that is directed in a positive way and is given the name of positive social behaviour. Altruism is basically concern for the welfare of others. True Altruism also includes sacrificing nature of a person who lose something for other than self, without expectation of any exchange or gain. It is related to the physical and psychological improvement to produce and maintain integrity of other persons. Altruism is basically concern for the welfare of others. True altruism also includes sacrificing nature of a person who lose something for other than self, without expectation of any exchange or gain. It is related to the physical and psychological improvement to produce and maintain integrity of other persons. ( Oommen 2015) in a study of self concept and academic achievement found significant correlation 
between self-concept and academic achievement of higher secondary students. He also explores significant difference between male and female students in their self-concept. Nair (2013) find relationship between quality of work life and organisational citizenship behaviour based on altruism and stated that there is a significant relationship between overall quality of work life and organisational citizenship behaviour based on altruism.

In the present study, the investigator has observe the relationship between Self-Concept and Altruism, if any, which contribute more in education of secondary school students regarding their gender and geographical areas.

\section{OBJECTIVES OF THE STUDY:}

1. To compare the Self-Concept of Male and Female secondary school students.

2. To compare the Self-Concept of Rural and Urban secondary school students.

3. To compare the Altruism of Male and Female secondary school students.

4. To compare the Altruism of Rural and Urban secondary school students.

5. To study the relationship between Self-Concept and Altruism of secondary school students.

\section{HYPOTHESES OF THE STUDY:}

1. There is no significant difference between the self-concept of male and female secondary school students.

2. There is no significant difference between the self-concept of rural and urban secondary school students.

3. There is no significant difference between the altruism of male and female secondary school students.

4. There is no significant difference between the Altruism of rural and urban secondary school students.

5. There is no significant relationship between the Self-Concept and Altruism of secondary school students.

\section{DELIMITATIONS:}

This study was confined to XII class 100 students of the secondary schools of Lucknow city only.

\section{METHODOLOGY}

The Descriptive research method was used for this study. All the schools of secondary level of district Lucknow of Uttar Pradesh, India along with students studying in class XII of these schools are taken as population. Sample of 100 secondary school students was selected through simple randomisation i.e. researcher has adopted the Simple Random Sampling technique Method for the selection of his sample. On the basis of gender, out of 100 students 50 were male and 50 were female students. While on the basis of geographical distribution 50 students were from rural and 50 students were from urban areas. In this study two tools have been used (i) Self- Concept Questionnaire prepared by Dr. R.K. Saraswat (2011) (ii) Altruism Scale prepared by Dr. S.N. Rai and Dr. Sanwat Singh (2004) namely. The Mean, S.D., " $t$ "-value and correlation (r) have been used for the analysis of collected data, and the obtained results were interpreted and explained qualitatively.

\section{ANALYSIS AND RESULTS}

1: For the verification of hypothesis Ho1 "There is no significant difference between the Self-Concept of senior secondary Male and Female students" is as below in table-1:

Table-1Analysis of Self-Concept of Male and Female Secondary School Students

\begin{tabular}{|l|l|l|l|l|l|l|l|}
\hline Gender & $\mathrm{N}$ & $\mathrm{M}$ & S.D. & SEd & df & t-value & Result \\
\hline Male & 100 & 182.95 & 16.25 & 2.379 & 98 & 1.66 & Not significant \\
\cline { 1 - 3 } & 100 & 186.91 & 17.29 & & & & \\
\hline
\end{tabular}

It is obvious from the table that the mean of self-concept of male students was 182.95 and mean of female students for the same variable was 186.91. The S.D. values are 16.25 and 17.29 for male and female secondary school students, respectively. The calculated t-test value is 1.66 at .05 level of significance. The table value at 98 degree of freedom at .05 level of significance is 1.98 that is higher than the calculated value. So, there is no significant difference between the self-concept of secondary male and female students. Hence null hypothesis Hol is accepted and retained. It means that male and female secondary school students have same levels of self concept.

2: Foe the verification of second null hypothesis Ho2 "There is no significant difference between the selfconcept of senior secondary rural and urban students", t-test was used by the researcher to obtained statistical values as shown in table- 2 . 
Table-2Analysis of Self-Concept of Rural and Urban Secondary school students

\begin{tabular}{|l|l|l|l|l|l|l|l|}
\hline Group & N & M & S.D. & SEd. & Df & t-value & Result \\
\hline Rural & 100 & 185.64 & 16.36 & 2.155 & 98 & 0.417 & Not Significant \\
\cline { 1 - 3 } Urban & 100 & 184.74 & 14.03 & & & & \\
\hline
\end{tabular}

It can be observed from the table-2 that the mean scores of self-concept of rural and urban secondary school students are 185.64and 184.74, respectively. The calculated S.D. values for rural and urban secondary school students are 16.36 and 14.03 respectively. The obtained t-value is 0.417 which is too much less from the critical value 1.98, necessary for the rejection of any null hypothesis at .05 level of significance with respect to degree of freedom 98. The null hypothesis Ho2 is being retained by the researcher. Thus, the rural and urban secondary school students are equal on levels of self concept.

3: For the verification of the hypothesisHo3"There is no significant difference between the Altruism of senior secondary Male and female students", the comparison was made on altruism of male and female secondary school students. it is shown in table -3 .

Table-3Analysis of Altruism of Male and Female Secondary School Students

\begin{tabular}{|l|l|l|l|l|l|l|l|}
\hline Group & N & M & S.D. & SED & Df & t-value & Result \\
\hline Male & 100 & 43.98 & 6.67 & 0.90 & 98 & 5.022 & Significant \\
\cline { 1 - 3 } Female & 100 & 48.50 & 6.12 & & & & \\
\hline
\end{tabular}

The above table values shown that the mean of altruism of secondary male students is, 43.98 and Mean of Altruism of Female secondary students is, 48.50. The S.D. values for both groups are 6.67 and 6.12 , respectively. The standard error of mean difference was 0.90 . The calculated "t"-test value is 5.022, which is much higher than the critical value 1.98. Therefore, the null hypothesis H03 is rejected at .05 level of significance. So, there is significant difference between the means of male and female altruism of secondary school students. This study reveals that Female students have more Altruistic behaviour than Male students at senior secondary level.

4: For the verification of the hypothesis Ho4 "There is no significant difference between the Altruism of senior secondary rural and urban students", t-test was applied on the data of altruism scale. The following table-4 shows different calculated values.

Table- 4Analysis of Altruism of Rural and Urban Secondary school students

\begin{tabular}{|l|l|l|l|l|l|l|l|}
\hline Group & N & M & S.D. & SEd & df & t-value & Result \\
\hline Rural & 100 & 44.26 & 6.29 & .867 & 98 & 2.11 & Not Significant \\
\cline { 1 - 4 } Urban & 100 & 46.08 & 5.97 & & & & \\
\hline
\end{tabular}

From the above table-4, we can state that the mean scores values of altruism for rural and urban secondary school students were 44.26and 46.08, respectively. When t-test was used, the calculated t-value was 2.11for rural and urban secondary school students. Critical value at .05 level of significance for $98 \mathrm{df}$ is 1.98 . It may be observed that calculated t-value 2.11 is little higher then critical value, therefore, the null hypothesis Ho4 rejected. This means that there is a significant difference between the mean scores of rural and urban secondary school students on altruism. This study leads conclusion that geographical areas affect the altruism level of secondary school students.

5: For the verification of the hypothesis Ho5 "There is no significant relationship between the SelfConcept and Altruism of senior secondary school students." Coefficient of correlation (r) was calculated. The obtained correlation coefficient (r) was written in the following table no. -5 .

Table-5 Analysis of Correlation between Self- Concept and Altruism of Secondary school students

\begin{tabular}{|c|c|c|c|c|c|}
\hline Correlation Group & $\mathrm{N}$ & $\mathrm{M}$ & S.D. & Correlation Coefficient (r) & Result \\
\hline Self-Concept & 200 & 184.93 & 16.84 & & \multirow{2}{*}{ Significant } \\
\hline Altruism & 200 & 46.24 & 6.24 & & \\
\hline
\end{tabular}

The above table-5 state that self concept and altruism of 200 students is 184.93 and 46.24, respectively. The correlation value ( $\mathrm{r}$ ) between self concept and altruism is 0.32 that is positive in direction and 0.32 in magnitude. This came in the category of low positive correlation. Therefore, the null hypothesis Ho5 is rejected. Although, the relationship found between the self concept and altruism was low positive for secondary school students. Thus self concept and altruism have considerable significant relationship. It explains that the altruism of the students somewhere affects the level of self- concept of secondary school students. 


\section{CONCLUSION}

The study revealed that The Self- Concept has no effect of gender difference and geographical areas. But altruism has significant effect of gender on secondary school students. Female students showed higher level of altruism than male students and geographical area also has little considerable influence on the level of altruism of secondary school students. The self-concept and altruism of secondary school students have low positively correlation with each other.

\section{REFERENCES}

[1] Baumeister, Roy F. (1999). The Self in Social Psychology. Psychology Press ; A member of the Taylor and Francis Group, USA. (ISBN: 0-86377-573-X).

[2] Guimond, Serge; Chatard, Armand; Martinot, Delphine; Crisp, Richard J.; Redersdorff, Sandrine (2006). "Social comparison, self-stereotyping, and gender differences in self-construals". Journal of Personality and Social Psychology. 90(2): 221-242 (doi:10.1037/0022-35.90.2.221. ISSN: 19391315.PMID.16536648).

[3] Henry,Epps ( ) Altruism: Charity and Hope for the World. Create Space independent Publishing Plateform, PP. 15. (ISBN 1-47826-3938)

[4] Marcengo, A. and Rapp, A. ( 2014). Visualization of human behavior. A chapter in Innovative approaches of data visualization and visual analytics, by (A.Huang, M.L. and Huang, W. 2014). A volume in the advanced in data mining and database management (ADMDM) Book Series, Information science reference ( an imprint of IGI Global), USA p; 238. (ISSN: 2327-1981;eISSN: 2327-199X)

[5] Nair, G.S. Sandhya (2013). A study on the effect of quality of Work life (QWL) on Organational Citizational citizenship behaviour (OCB) - with special reference to college Teachers is Thrissur District, Kerala. Integral Review- A journal of Management, Vol.6, No. 1. p-ISSN : 0974-8032, e- ISSN : 22786120, Vol. 6 No. 1, pp 34 - 46 http://intergraluniversity.ac.in/net/journals Andpublications.aspx

[6] Oommen, N. Maria (2015). Self Concept and Academic Achievement among Students at Higher Secondary Level. International Journal of Scientific Engineering and Research (IJSER) ISSN (Online): 2347-3878, Impact Factor (2014): 3.05, Volume 3 No. 7.

[7] Rogers, C. (1951). Client-cantered therapy: Its current practice, implications and theory. London: Constable.

[8] Wispe, Lauren (1978). Altruism, Sympathy, and Helping: Psychological and Sociological principles. Academic press, 